\title{
CHARACTERISTICS OF POVERTY IN THE REPUBLIC OF SERBIA
}

\author{
Žarko Đorić $^{1}$
}

\begin{abstract}
Poverty analysis helps to focus the attention of government and civil society on the poor and the living conditions in which they live. Poverty and, as the central theme of this article, is one of the biggest and most visible problems of every transition society including Serbia. The text of this analysis is organized as follows. In the first part, the conceptual and theoretical definition of poverty is briefly presented. The second part gives a description of the cause of poverty and points to its complexity. The third part presents a cognition of the distribution, depth and nature of poverty and inequality of income in Serbian society, while the fourth part, as the last section, offers a proposal for measures for suppression of poverty. The method of the case - study was used in this paper, in order to better examine the nature and depth of poverty in the Republic of Serbia on the basis of relevant research.
\end{abstract}

Key words: poverty, Gini coefficient, economic growth, education

JEL Classification: A13, D31, I32

\section{INTRODUCTION}

Poverty is a very complex, multi-dimensional, long-lasting, persistent, durable and common social problem for all of today's societies. And in recent times, there is a lot of writing about the problem and the phenomenon of poverty, as evidenced by the large number of papers on this topic (see for example: Tsaurai, 2018; Fosu, 2017; De La O Campos et al., 2018; Kneebone, 2018; Page \& Pande, 2018; Banks et al., 2017; Bernstein et al., 2018; Laird et al., 2018; Dapel, 2018; Addison et al., 2017; Wan \& Wang, 2018).

Figure 1 is shown poverty and social inequality as one of the three following topics you can find the most worrying in your country. Serbia ranked on third place in the world regarding the citizens' concerns when it comes to the problem of poverty. As many as $51 \%$ of the population expressed concern about poverty and social inequality, which is a clear signal of the importance of this topic. The eradication of poverty is a moral and ethical obligation that is based on the principles governed by the United Nations, and it was exactly what was set for the first goal of the Millennium Development Goals.

\footnotetext{
${ }^{1}$ Žarko Đorić, Niš, E-mail: zdjoric82@gmail.com
} 
Figure 1.: Do you find Poverty \& Social Inequality as the most worrying in your country?

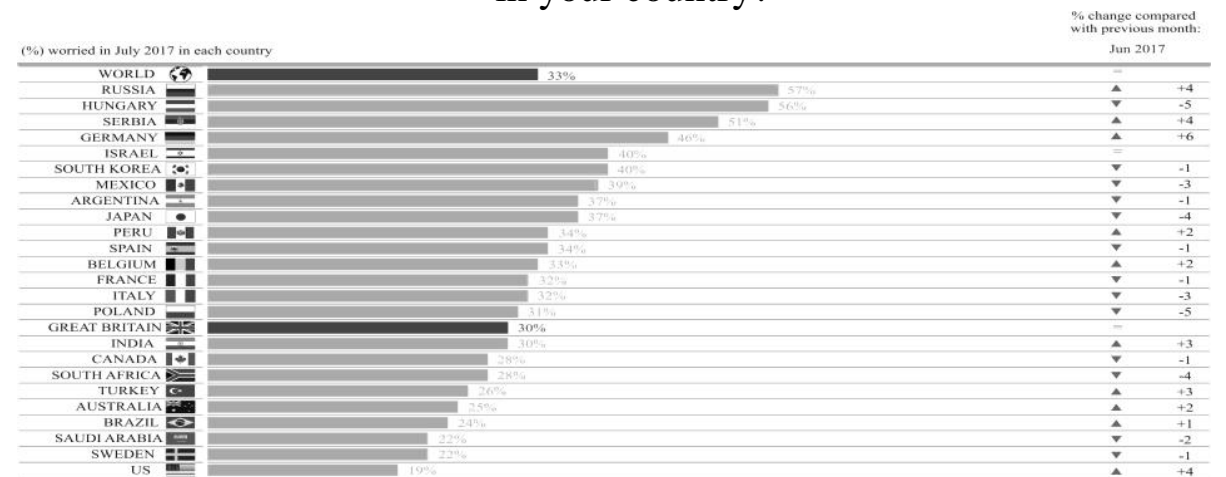

Base: Representative sample of adults aged 16-64 in 26 participating countries. July 2017: 18,557; June 2017: 19,530.

Source: Ipsos Public Affairs World Worries | July 2017 | Version 1: https://www.ipsos.com/sites/default/files/2017-08/What_worries_the_world-July2017.pdf (accessed on 10. 9. 2018), p. 16

\section{WHAT POVERTY IS?}

Although scientists have offered numerous answers to the problem of poverty, it remains a serious, global and growing problem. Poverty is difficult to define because it is a relative and subjective term, and for different people has a different meaning. Economists define poverty most often as an inability to reach a certain standard of living. Economists and sociologists differ absolute and relative poverty, or, the income threshold. Absolute poverty refers to the lack of funds for basic needs such as food, clothing and shelter, and can be defined as a state in which the level of income can not cover the estimated cost of living at the existential level, that is, the cost of survival. Relative poverty takes into account the social and economic status of an individual in relation to the rest of society. Someone is considered to be affected by poverty when his income, although sufficient to survive, is significantly lagging behind his community. Poverty is most often measured in monetary terms, captured by levels of income or consumption per capita or per household. According to the new official UN criterion, absolutely poor people are considered to be people living on less than $\$ 1.25$ per day. The World Bank has defined a new poverty line at the international level of $\$ 1.25$ per day in 2008, and in October 2015 it was set at $\$ 1.90$ per day. ${ }^{2}$

Broken down by risk factors, a total of $25.5 \%$ of the population of the Republic of Serbia (1.79 million people) were at risk of poverty,

\footnotetext{
${ }^{2}$ http://www.worldbank.org/en/topic/poverty/brief/global-poverty-line-faq
} 
$19.5 \%$ (1.37 million people) were severely materially deprived, and $15.7 \%$ (1.01 million people) lived in households with low work intensity (Government of the Republic of Serbia, 2018, p. 81). The at-risk-ofpoverty rate in the Republic of Serbia is considerably higher than the average at-risk-of-poverty rate in the EU-28 (17.3\%) (Government of the Republic of Serbia, 2018, p. 21). In 2015, the at-risk-of-poverty threshold or relative poverty line, calculated as $60 \%$ of the median equivalised income, amounted to, on average, RSD 15,416 per month for a singleperson household, and RSD 32,374 for a four-member household with two adults and two children up to the age of 14 (Government of the Republic of Serbia, 2018, p. 83).

\section{POVERTY - CAUSES, COMPLEXITIES AND CHALLENGES}

Dimensions that are identified as significant for understanding and conceptualizing the notion of poverty are the material standard (income, consumption and assets), health, education, individual activities (including work), political influence, social contacts and relationships, the environment and uncertainty (economic and physical) (Stiglitz et al., 2009, p. 14-15). Poverty is accompanied by an ultimate lack of resources for living, poor housing, primitive and scanty way of dressing, chronic hunger and permanent partial satisfaction of basic living needs (Figure 2).

The causes of poverty in contemporary society are numerous - the individual's responsibility for their situation (laziness, incompetence, asociality, lack of adequate abilities and motivation), wider social processes and structural factors (education, class affiliation, lack of means of subsistence, long-term economic underdevelopment, poor social mobility, unequal distribution of income and resources within countries and globally, conflicts in some parts of the world, etc.) and natural disasters (floods, droughts, earthquakes, global warming, acid rain, etc.).

In addition to unemployment, one of the causes of further deepening poverty in developing and transition countries is the globalization process. Globalization as a megatrend, which significantly determines contemporary social and economic trends, among other things, results in the liberalization of the labor market and the privatization of state-owned firms, which often leads to inequality in income within the country (Roganović, 2017, p. 23). In globalization, money plays an important role. Thanks to globalization, financial oligarchs achieve global planning of financial flows and control over the redistribution of resources (Milačić, Kostić, 2018, p. 4). It's at work corporate society and his rules are merciless: the imperative of profit, the imperative of growth, competition and aggressiveness, amoralism, hierarchy, segmentation, 
dehumanization, exploitation, ephemerality and mobility, disparity with nature, homogenization, etc. (Milačić, Kostić, 2018, p. 5). The neoliberal concept is completely contrary to the concept of welfare states and results in a reduction in public spending and reduced allocations for social solidarity and social protection. In this way, the doctrine of market fundamentalism leads to an increasing deepening of the gap between the rich and the poor. The exit strategy should be sought in a new mode of governance in order to put globalization in service of those who need it most, and they are the poorest.

Figure 2.: The Web of poverty's disadvantages

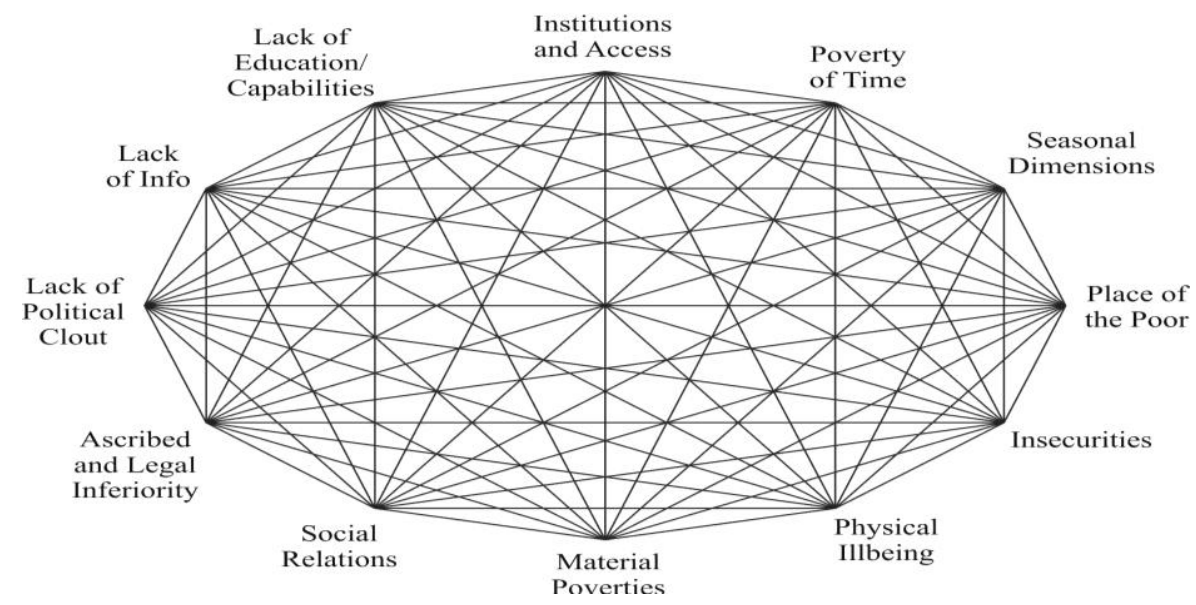

Source: UNDP, 2006, p. 3

Poverty is associated with some demographic and social characteristics (gender, age, economic activity, etc.), which means that all categories of population are not equally at risk of poverty. In all societies, the risk of poverty is exposed to: (long-term) unemployed, certain categories of employees (older workers, those who work half-time or their jobs are insecure), young and old, sick and disabled, children, women, families and single-parent households, ethnic minorities, etc.

In its latest report, the World Bank is considering two highervalue poverty lines of US\$3.20 and US\$5.50 per person per day, expressed in 2011 PPP, which reflect social assessments of what defines minimum basic needs in in lower-and upper-middle-income countries, respectively. Almost half the world (46\%) lives on less than US\$5.50 per day, while a quarter of the world $(26,3 \%)$ lives on less than US\$3.20 per day (Table 1), which clearly indicates that poverty remains one of the most complex world challenges. 
Table 1.: Poverty at Higher Poverty Lines, US $\$ 3.20$ and US $\$ 5.50$ (2011PPP)

\begin{tabular}{|l|l|l|l|}
\hline $\begin{array}{l}\text { Poverty rate by } \\
\text { region at US\$3.20 }\end{array}$ & $\mathbf{2 0 1 5}$ & $\begin{array}{l}\text { Poverty rate by } \\
\text { region at US\$5.50 }\end{array}$ & $\mathbf{2 0 1 5}$ \\
\hline East Asia and Pacific & 12.5 & East Asia and Pacific & 34.9 \\
\hline Europe and Central Asia & 5.4 & Europe and Central Asia & 14.0 \\
\hline $\begin{array}{l}\text { Latin America and the } \\
\text { Caribbean }\end{array}$ & 10.8 & $\begin{array}{l}\text { Latin America and the } \\
\text { Caribbean }\end{array}$ & 26.4 \\
\hline $\begin{array}{l}\text { Middle East and North } \\
\text { Africa }\end{array}$ & 16.3 & $\begin{array}{l}\text { Middle East and North } \\
\text { Africa }\end{array}$ & 42.5 \\
\hline South Asia & $48.6^{\mathrm{a}}$ & South Asia & $81.4^{\mathrm{a}}$ \\
\hline Sub-Saharan Africa & 66.3 & Sub-Saharan Africa & 84.5 \\
\hline Rest of the world & 0.9 & Rest of the world & 1.5 \\
\hline World & 26.3 & World & 46.0 \\
\hline
\end{tabular}

Note: PPP = purchasing power parity.

a. The estimate is based on regional population coverage of less than 40 percent. The criteria for estimating survey population coverage is whether at least one survey used in the reference year estimate was conducted within two years of the reference year.

Source: adapted from: World Bank, 2018, p. 8

Poverty has consequences for society (socio-pathological phenomena, weakening of social cohesion, burden of social security funds) and for an individual (conflicts, neurosis, personal dissatisfaction, social exclusion, fears, a sense of helplessness, illness, death, etc.). According to Europe 2020 strategy, in order for economic growth to be inclusive, the goal of fighting against poverty and social exclusion must be introduced into the creation of all public policies.

\section{POVERTY IN SERBIA - PROFILE, ACHIEVMENTS, KEY FACTS AND ATUAL TRENDS}

Poverty in Serbia is a long-term phenomenon, conditioned by social and economic contradictions. We can look at poverty in Serbia in context of postponed processes of post-socialist transformation, as well as current and forthcoming processes in the EU accession. Poverty in Serbia is a huge problem, not only because of its widespread, but also because of very difficult and bad consequences.

After political change in 2000 , commitment to poverty reduction and reform of the social security system is indisputable. The economic progress achieved, as well as the redefinition of the social protection system, influenced the number of persons living below the absolute poverty line in just a few years to halve. The poverty headcount fell by more than half from $14 \%$ in 2002 to $6.6 \%$ in 2007, according to the LSMS data (see Figure 3), which is the result of strong economic growth during this period as well as the growth of pensions and other social 
transfers. However, the sustainability of a positive trend in the growth of living standards of the population has been largely put into question since the effects of the global economic crisis began to appear in Serbia at the end of 2008 and early 2009. The negative trends in the economy caused by the World Economic Crisis have affected the growth of poverty since 2008.

Figure 3.: Poverty Headcount (Percent) and Real GDP per Capita

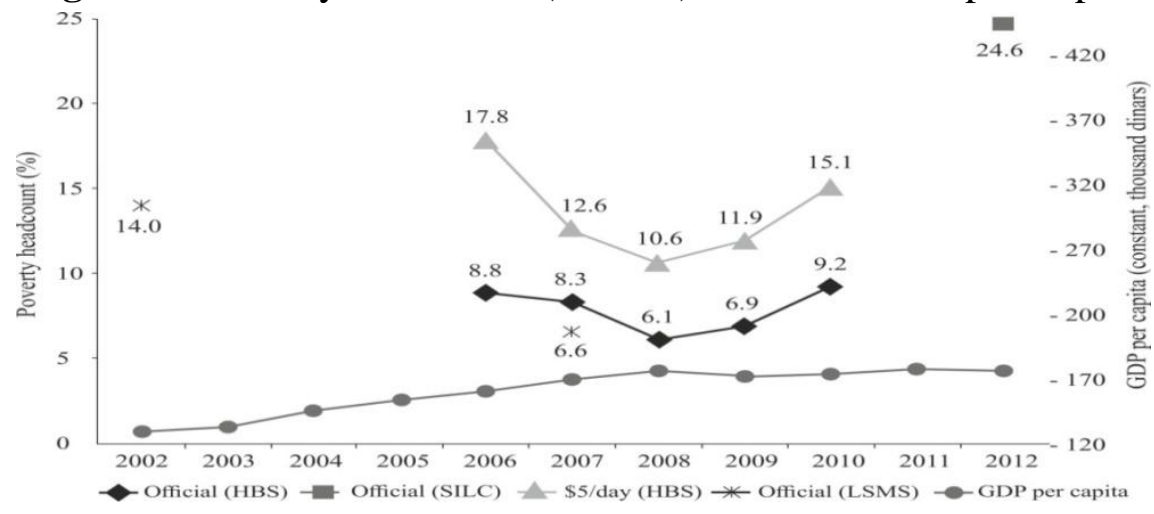

Note: Official poverty estimate in 2012 is based on income (EU-SILC data). Previous year estimates are based on consumption (LSMS and HBS data).

Source: World Bank, 2015, p. 7

In 2016, the poverty line stood at RSD 11,694 per equivalent adult per month, and $7.3 \%$ of the Republic of Serbia's population had consumption below this level. This value of poverty line is a result of regular annual adjustment for the amount of inflation since 2006, when the line was originally constructed. Each person whose monthly consumption is below this level falls into the absolutely poor category. Poverty incidence cannot be said to have decreased significantly over the observed medium-term period 2011-2016. (Table 2).

Table 2.: Absolute poverty* in the Republic of Serbia

\begin{tabular}{|l|c|c|c|c|c|c|}
\hline & $\mathbf{2 0 1 1}$ & $\mathbf{2 0 1 2}$ & $\mathbf{2 0 1 3}$ & $\mathbf{2 0 1 4}$ & $\mathbf{2 0 1 5}$ & $\mathbf{2 0 1 6}$ \\
\hline $\begin{array}{l}\text { Poverty line, } \\
\text { per } \\
\text { equivalent } \\
\text { adult per } \\
\text { month, RSD }\end{array}$ & 9,483 & 10,223 & 11,020 & 11,340 & 11,556 & 11,694 \\
\hline $\begin{array}{l}\text { Poverty } \\
\text { incidence }\end{array}$ & $\mathbf{6 . 6}$ & $\mathbf{6 . 3}$ & $\mathbf{7 . 4}$ & $\mathbf{7 . 6}$ & $\mathbf{7 . 4}$ & $\mathbf{7 . 3}$ \\
\hline $\begin{array}{l}\text { Poor } \\
\text { population }\end{array}$ & 485,407 & 459,615 & 524,908 & 534,044 & 515,663 & 492,306 \\
\hline Population & $7,343,047$ & $7,303,771$ & $7,096,115$ & $7,064,646$ & $6,927,866$ & $6,755,343$ \\
\hline
\end{tabular}

*Absolute poverty entails the inability to meet the essential, minimum, basic needs. Source: Based on: Mladenović, 2017 
In 2016, the last year observed, $7.3 \%$ of the population was absolutely poor, while the reductions in the absolutely poor population were primarily a result of population decline. The consumption of approximately half a million people was not sufficient to meet the basic subsistence needs.

When we are talking about territorial and regional distribution, poverty is twice as common in non-urban areas (Figure 4). Rural poverty is one of the basic characteristics of poverty in Serbia. In rural areas, the poor are disproportionally located and are mainly engaged in agriculture and similar activities. The neglect of rural regions in Serbia, poor infrastructure, economic and technological backwardness, the traditional presence of poverty (income less than $\$ 2$ per day), condition many villages isolated, which results in the abandonment and extinction of certain villages (Mirković, 2010). Poverty is no longer concentrated and limited to traditionally underdeveloped areas (South Serbia), but also extends to Eastern, certain parts of Central Serbia and regional centers of mining and industry in Western Serbia. The regional breakdown reveals the highest poverty incidence values in the region of Southeastern Serbia, where the poorest population makes up a quarter of the total number of poor people. The Belgrade Region consistently had the lowest poverty incidence and the convergence of the Vojvodina and Sumadija and Western Serbia Regions with the Belgrade Region was identified as a positive trend in the observed period (Figure 5).

Figure 4.: Poverty incidence by settlement type

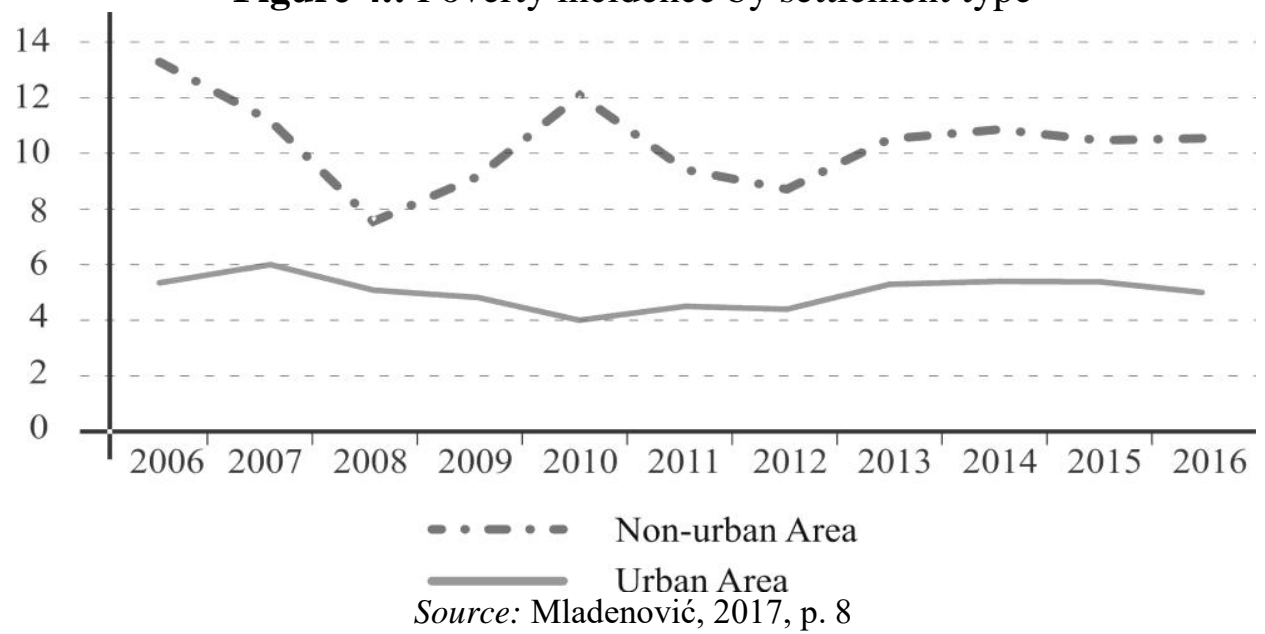

Vol. 21, бpoj 1/2019, стр. 65-79 
Figure 5.: Poverty incidence by region

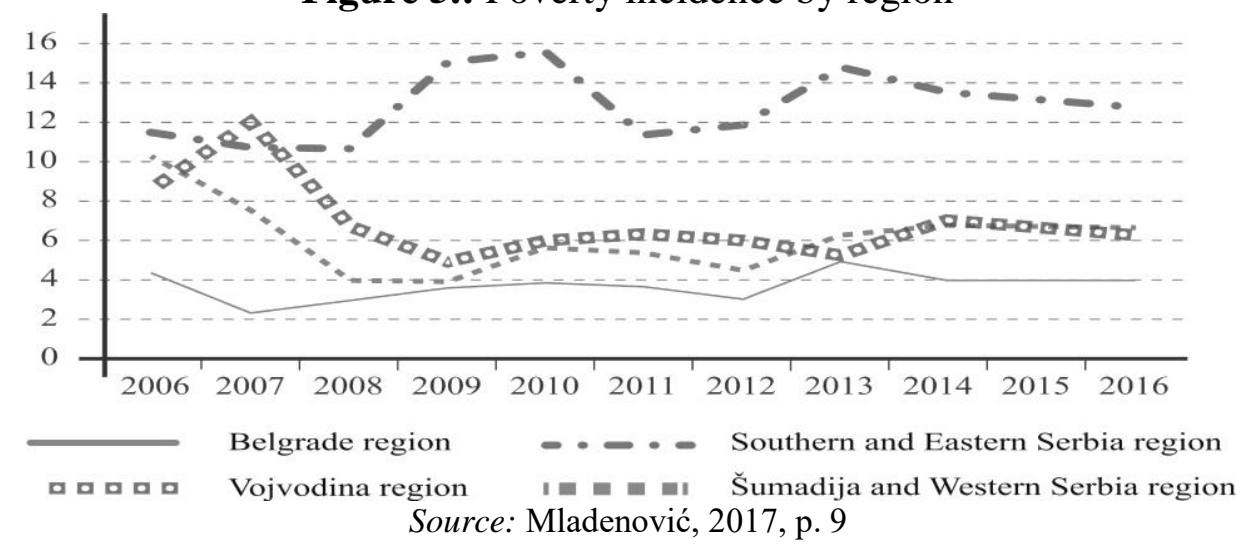

The poverty and dynamics of poverty in a country depends not only on the degree of economic development, but also on economic inequalities. Consumption inequality is monitored through two indicators: the Gini coefficient (which measures inequality in the population as a whole and takes values from 0 to 1 , or from 0 to 100 , where 0 indicates full consumption equality of all individuals, and 1 or 100 denotes absolute concentration of all consumption in one individual) and the consumption quintile share ratio (the ratio of the consumption of the richest $20 \%$ to that of the poorest $20 \%$ of the population). Income inequality is very high in the Republic of Serbia, according to both the income quintile share ratio (S80/S20) and the Gini coefficient. In the observed period from 2011 to 2016, both indicators exhibited a slight increase (Table 3 and Table 4).

Table 3.: Gini coefficient

\begin{tabular}{|l|c|c|c|c|c|c|}
\hline & $\mathbf{2 0 1 1}$ & $\mathbf{2 0 1 2}$ & $\mathbf{2 0 1 3}$ & $\mathbf{2 0 1 4}$ & $\mathbf{2 0 1 5}$ & $\mathbf{2 0 1 6}$ \\
\hline $\begin{array}{l}\text { Republic of } \\
\text { Serbia }\end{array}$ & 25.38 & 26.76 & 26.90 & 26.65 & 25.54 & 26.13 \\
\hline
\end{tabular}

Source: Based on: Mladenović, 2017

Table 4.: Consumption quintile share ratio, s80/s20

\begin{tabular}{|l|c|c|c|c|c|c|}
\hline & $\mathbf{2 0 1 1}$ & $\mathbf{2 0 1 2}$ & $\mathbf{2 0 1 3}$ & $\mathbf{2 0 1 4}$ & $\mathbf{2 0 1 5}$ & $\mathbf{2 0 1 6}$ \\
\hline $\begin{array}{l}\text { Republic of } \\
\text { Serbia }\end{array}$ & 3.60 & 3.93 & 4.00 & 3.90 & 3.70 & 3.89 \\
\hline
\end{tabular}

Source: Based on: Mladenović, 2017

Based on the draft laws on statistics, the Republic Institute of Statistics (RZS), has been granted the authority and the right to monitor the development of poverty in Serbia in order to identify the most sensitive population groups and the main poverty risk factors. In order to gain a wider picture of poverty in Serbia, we will report the results of the poverty analysis for the last available 2016, made with the help of the 
Survey on Income and Living Conditions, done with the RZS (Републички завод за статистику, 2017). RZS announced that the poverty rate in Serbia in 2016 is $25.5 \%$ that is, a quarter of citizens are at risk of becoming poor. According to the RZS, rate of risk of poverty or social exclusion in 2016 was $38.7 \%$. Risk of poverty is the most stressed among young people aged 18-24 (32.7\%), then under the age of 18 $(30.2 \%)$, while the lowest rate of risk for the poor has a population older than 65 years $(19.1 \%)$. The highest rate of poverty risk is that of people living in households consisting of two adults with three or more dependent children $(49.8 \%)$ and persons under 65 who are one-person households $(40.1 \%)$. When it comes to working status, the risk of poverty is the most exposed to adult-age unemployed citizens (48\%), while the lowest risk-of-poverty rate is for employed by the employer (9\%). About a third of self-employed people are at risk of poverty, while about $15.4 \%$ of pensioners are exposed to that risk. According to the obtained results, the poverty risk rate (these persons are not necessarily poor, but only have a higher risk of being) is $25.5 \%$. (Table 5).

In addition, rate of risk of poverty or social exclusion (these persons are at risk of poverty or are severely materially deprived or living in households with very low labor intensity) in 2016 is $38.7 \%$. The threshold of poverty risk (relative poverty line) in 2016 is $15.416,00 \mathrm{RSD}$ per month for a one-member household. For households with two adults and one child up to 14 years of age, the threshold of poverty risk is 27,748.82 dinars, while for a four-member household with two adults and two children up to 14 years old, this threshold is 32,373,63 dinars. Observed by age, persons 18-24 are most at risk of poverty (32.7\%), as well as persons under the age of $18(30.2 \%)$. (Table 5). The lowest rate of poverty risk is for people over $65(19.1 \%)$. The highest rate of poverty risk is that of persons in households who make up two adults with three or more dependent children ${ }^{3}, 49.8 \%$, then persons under 65 who live in single-member households, $40.1 \%$. Depending on the working status, for persons aged 18 and over, the most at-risk of poverty are unemployed persons $(48.0 \%)$ while the lowest risk-of-poverty rate is for employed by the employer $(9.0 \%)$. Self-employed are also very vulnerable, and their poverty risk rate is $32.4 \%$, pointing out that self-employment in Serbia is often reduced to "last-resort jobs". They have a higher risk of poverty than employed by employers (9\%), and one part of the self-employed deals with the gray economy where wages are lower. Long-term unemployment can reduce economic mobility and cause a sort of "poverty

\footnotetext{
${ }^{3}$ The term "dependent child" refers to all persons under the age of 18, as well as to persons aged 18-24 who live with at least one parent and are economically inactive.
}

Vol. 21, бpoj 1/2019, стр. 65-79 
trap", which is why it is considered that employment and inclusion in the labor market is one of the important prerequisites for economic independence and taking responsibility at the individual level and economic growth as a whole. Poverty risk for pensioners is $15.4 \%$ (Table 6). There is important role of the pension system in elderly poverty reduction. Thus, without pensions, the elderly population's at-risk-ofpoverty rate would exceed $80 \%$, and when all pension types are taken into consideration, it amounts to $19.1 \%$ (Government of the Republic of Serbia, 2018, p. 231).

Table 5.: Poverty risk rate by gender and age ${ }^{4}, \%$

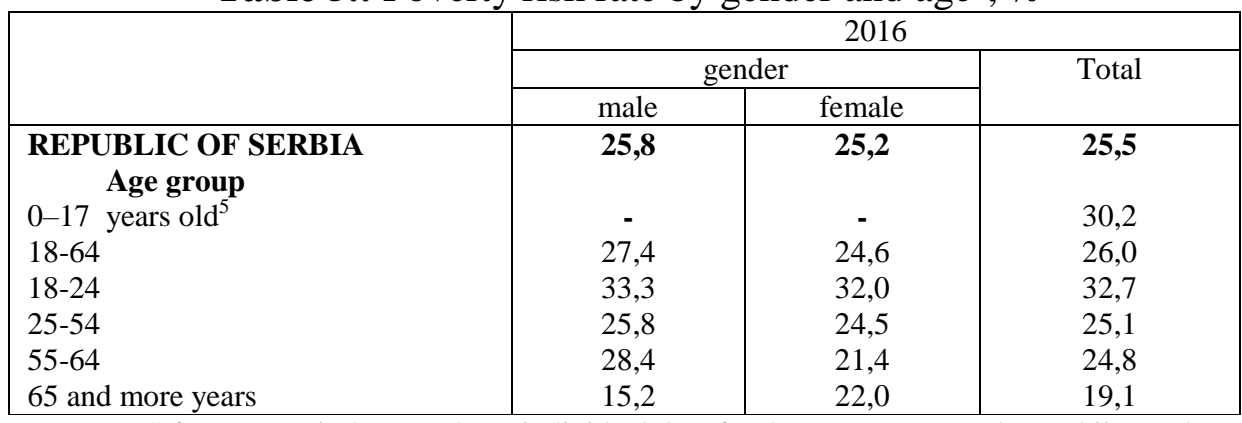

Note: RZS from 1999. it does not have individual data for the AP Kosovo and Metohija, so they are not included in the coverage of the data for the Republic of Serbia (total).

Source: Републички завод за статистику (2017)

Table 6.: Poverty risk rate according to the most common status in the labor market and gender (for people aged 18 and over), ${ }^{6}, \%$

\begin{tabular}{|l|c|c|c|}
\hline \multirow{2}{*}{} & \multicolumn{2}{|c|}{2016} \\
\cline { 2 - 3 } & \multicolumn{2}{|c|}{ gender } & \multirow{2}{*}{ Total } \\
\cline { 2 - 3 } & male & female & \\
\hline Working & $\mathbf{1 4 , 8}$ & $\mathbf{9 , 9}$ & $\mathbf{1 2 , 6}$ \\
Employed by the employer & 10,2 & 7,7 & \\
Self-employed & & 29,2 & 9,0 \\
Do not work & 33,7 & $\mathbf{3 0 , 1}$ & 32,4 \\
Unemployed & $\mathbf{3 1 , 9}$ & 44,9 & $\mathbf{3 0 , 9}$ \\
Pensioners & 50,8 & 16,9 & 48,0 \\
Others inactive & 13,3 & 36,7 & 15,4 \\
& 29,8 & 34,7 \\
\hline
\end{tabular}

Source: Републички завод за статистику. (2017).

\footnotetext{
${ }^{4}$ Reference period: previous year in relation to the year indicated in the table

5 For the age group 0-17 years, only the total poverty risk rate is shown, without gender division.

${ }^{6}$ Reference period: previous year in relation to the year indicated in the table

${ }^{7}$ Self-employed persons include farmers.
} 


\section{POSSIBILITY OF POVERTY REDUCTION AND POLICY OF INTERVENTION}

There are various ways and recommendations for coping with poverty and its eradication in modern society. According to Aoun (2004, p. 23) the most important elements for any strategy to fight poverty and poverty alleviation in the developing countries are: (1) investment in human capacity, (2) capital formation (accumulation of capital), (3) entrepreneurship, (4) international trade (gain a larger share of world exports, and create precondition to improve standard of living of the poor in the country), (5) give top priority to rural development since the majority of the poor live in the rural areas and (6) equity and environmental quality.

To eradicate poverty of key importance are strong institutions, social enterprise and good public governance in terms of protection of property rights, strong rule of law and control of corruption. However, undoubtedly the best way to eradicate poverty is strong and sustained economic growth. As for Serbia it is optimal sustainable annual growth rate of 5\% and more and it can be achieved through: 1. social system reforms in order to increase savings and investment based on domestic savings; 2. effective active employment policy, in order to qualify labor for market needs; 3 . increasing the technological base of production in order to increase productivity and competitiveness, as well as significantly increase the efficiency of the institutions by relying on simple rules and e-administration and 4 . fiscal and monetary politics that take into account the competitiveness of the economy, since sustained growth will have to be secured by reliance on export growth (Рогановић, 2017, p. 238).

An important element in combating social exclusion and poverty reduction is the establishment of a transparent and accessible system of banking services. Taking into account that inflation reduces the real wage of the poor it can be said that conservative monetary policy is good for the poor. This paper also argues that public investment (specially public investment in infrastructure) has to be a priority for the countries of the south because, as it is demonstrated, it is one of the key pillars to promote development and to eradicate poverty. Further strengthening of democratic institutions and the opening of Serbia in a stronger integration with Europe and the global economy should also be a way of reducing poverty.

Vol. 21, број 1/2019, стр. 65-79 


\section{CONCLUSION}

Regarding the poverty structure in Serbia, the greatest risk of poverty have: the most deprived is the population living outside of urban areas, especially in central Serbia, children and young people, uneducated, unemployed, multi-person households and inactive holders of households (see: Government of the Republic of Serbia, 2018). In circumstances while more than half a million inhabitants of Serbia are not able to meet the most basic needs, it is important to monitor a nationally specific indicator - absolute poverty by consumption. Serbia must not return to inflationary budget financing, and therefore, it has to design a social sector in accordance with its capabilities, rather than wishes. A crucial preconditions for ending extreme poverty are: (1) strong political commitment, including dedicated resources, strong institutions and empowered citizens; (2) effective political leadership that creates conditions for the participation of all (or most) sectors of society in decision-making processes, such as women, youth, persons with disabilities, older persons, and indigenous peoples and (3) strong private sector, through leveraging investments and social responsibility (De La O Campos et al., 2018, p. 38-40).

\section{REFERENCES}

1. Addison, T., Pikkarainen, V., Rönkkö, R., Tarp, F. (2017). Development and poverty in sub-Saharan Africa, WIDER Working Paper 2017/169, September 2017, United Nations University World Institute for Development Economics Research.

2. Aoun, A. (2004). Poverty Alleviation in the Developing Economies: the Leading Issues. NEW MEDII, N. 1/2004, 18-23.

3. Banks, L. M, Kuper, H., \& Polack, S. (2017). Poverty and disability in low-and middle-income countries: A systematic review. PLoSONE, 12(12), 1-19.

4. Bernstein, S.F, Rehkopf, D., Tuljapurkar, S., \& Horvitz, C.C. (2018). Poverty dynamics, poverty thresholds and mortality: An age-stage Markovian model. PLoSONE, 13(5), 1-21.

5. Dapel, Z. (2018). Will the Poor in Nigeria Escape Poverty in Their Lifetime?, CGD Working Paper 483. Washington, DC: Center for Global Development.

6. De La O Campos, A.P., Villani, C., Davis, B., \& Takagi, M. (2018). Ending extreme poverty in rural areas - Sustaining 
livelihoods to leave no one behind. Rome, FAO. 84 pp. Licence: CC BY-NC-SA 3.0 IGO.

7. Fosu, A.K. (2017). Growth, inequality, and poverty reduction in developing countries: Recent global evidence. Research in Economics, 71(2017), 306-336.

8. Government of the Republic of Serbia (2018). Third national report on social inclusion and poverty reduction in the Republic of Serbia, The Status of Social Exclusion and Poverty Trends in the Period 2014-2017 and Future Priorities, Belgrade, December 2018: $\quad$ https://media.srbija.gov.rs/medeng/documents/thirdnational-report-on-social-inclusion-and-poverty-reduction201417_eng.pdf (accessed on 22. 1. 2019).

9. http://www.worldbank.org/en/topic/poverty/brief/global-povertyline-faq

10. Ipsos Public Affairs World Worries (2017, July) Version 1: https://www.ipsos.com/sites/default/files/201708/What_worries the world-July-2017.pdf (accessed on 10. 9. 2018).

11. Kneebone, R. (2018). Housing, Homelessness and Poverty. SPP Briefing Paper, Volume 11:29, November 2018, 1-9.

12. Laird, J., Parolin, Z., Waldfogel, J., \& Wimer, C. (2018). Poor State, Rich State: Understanding the Variability of Poverty Rates across U.S. States. Sociological Science, 5, 628-652.

13. Milačić, S., Kostić, A. (2018). Problems of Socioeconomic Development in the Conditions of Contemporary Globalization. [Problemi društveno-ekonomskog razvoja u uslovima savremene globalizacije]. Ekonomski pogledi, 20(2), 1-15.

14. Mirković, M. (2010). Integrated rural development as a poverty reduction factor [Integralni ruralni razvoj kao faktor smanjenja siromaštva]. Ekonomski pogledi, 12(1), 45-54.

15. Mladenović, B. (2017). Poverty in the Republic of Serbia $2006-$ 2016, Revised and New Data, Belgrade: Social Inclusion and Poverty Reduction Unit, Government of the Republic of Serbia, August, $2017:$ http://socijalnoukljucivanje.gov.rs/wpcontent/uploads/2017/09/Po verty-in-the-Republic-of-Serbia-for-the-Period-2006 
\%E2\%80\%93-2016-\%E2\%80\%93-Revised-and-New-Data.pdf (accessed on 18. 9. 2018).

16. Page, L., \& Pande, R. (2018). Ending Global Poverty: Why Money Isn't Enough. Journal of Economic Perspectives, Volume 32, Number 4, Fall 2018, 173-200.

17. Republički zavod za statistiku. (2017). Anketa o prihodima i uslovima života. Siromaštvo i socijalna nejednakost u Republici Srbiji. Saopštenje: http://www.stat.gov.rs/sr-latn/oblasti/potrosnjaprihodi-i-uslovi-zivota/prihodi-i-uslovi-zivota/ (accessed on 25. 11. 2018).

18. Roganović, M. (2017). Analysis of poverty problem in the Republic of Serbia - causes, consequences and possibilities for elimination [Analiza problema siromaštva u Republici Srbiji uzroci, posledice i mogućnosti otklanjanja]. Doktorska disertacija, Univerzitet Privredna Akademija u Novom Sadu, Fakultet za ekonomiju i inženjerski menadžment u Novom Sadu.

19. Stiglitz, J., Sen, A., \& Fitoussi, J.P. (2009). Report by the Commission on the Measurement of Economic Performance and Social

Progress: https://ec.europa.eu/eurostat/documents/118025/118123/Fitoussi+ Commission+report (accessed on 23. 10. 2018).

20. Tsaurai, K. (2018). The Impact of Remittances on Poverty Alleviation in Selected Emerging Markets. Comparative Economic Research, 21(2), 51-68.

21. UNDP (2006). Poverty in Focus. What is poverty? Concepts and measures, International Poverty Centre, December 2006: https://ipcig.org/pub/IPCPovertyInFocus9.pdf (accessed on 28. 10. 2018).

22. Wan, G., Wang, C. (2018). Poverty and inequality in Asia 19652014, WIDER Working Paper 2018/121, September 2018, United Nations University World Institute for Development Economics Research.

23. World Bank (2015). Republic of Serbia, Country Partnership Framework 2016-2020. Document of The World Bank Group, Report No. 100464-YF, May 2015.

24. World Bank (2018). Poverty and Shared Prosperity 2018. Piecing Together. The Poverty Puzzle, World Bank, Washington, DC: 
https://openknowledge.worldbank.org/bitstream/handle/10986/304 18/9781464813306.pdf (accessed on 29. 1. 2019).

Рад је примьен: 12.04 .2019$. Коригована верзија рада је примљена: 18.04.2019. Рад је прихваћен за штампу: 20.04.2019. 